BEYOND PLURALISM

\title{
Pendekatan Open Integrity Gerardette Philips sebagai Sebuah Upaya Dialog Pluri-Religius dalam Berteologi Interreligius di Indonesia
}

\author{
YEHEZKIEL RICHARD HALOMOAN SIAGIAN \\ Universitas Kristen Duta Wacana, Yogyakarta \\ DOI: 10.21460/aradha. 2021.11.548
}

\begin{abstract}
An openness to claims of truth, a response to relativism, and maintaining the uniqueness of each religion are the issues that the authors will discuss in this paper. In this paper, the approach of pluralism will be looked at again to build the integrity of each religion that is considered typical to be maintained. This study intends to build open integrity through Gerardette Philips's writings on dialogue in interreligious relationships that each adherent hopes can be rooted in his religion but go to the heart of another religion. There is no way to deny the truth of the religion itself to understand the truth of another religion in a dialogue, but there is also no valuable value in other religions to be denied. The open integrity approach moves beyond pluralism and relativism.
\end{abstract}

Keywords: interreligious, pluralism, relativism, open integrity

\section{Abstrak}

Keterbukaan terhadap klaim kebenaran, respon pada relativisme, dan mempertahankan keunikan masing-masing agama adalah isu yang akan dibahas oleh penulis pada tulisan ini. Dalam tulisan ini, pendekatan pluralisme akan dilihat kembali dalam upaya membangun integritas masing-masing agama yang dianggap sebagai khas untuk dipertahankan. Studi ini berniat untuk membangun sebuah integritas yang terbuka melalui tulisan Gerardette Philips mengenai dialog dalam relasi interreligius yang diharapkan setiap penganut dapat berakar 
pada agamanya sendiri namun masuk ke jantung agama lain. Tidak ada cara untuk menolak kebenaran agama sendiri untuk mengerti kebenaran dari agama lain dalam sebuah dialog yang dilakukan, namun juga tidak ada nilai yang berharga dalam agama-agama lain yang harus disangkal. Pendekatan open integrity bergerak melampaui pluralisme dan relativisme.

Kata-kata kunci: interreligius, pluralisme, relativisme, integritas, terbuka

\section{Pendahuluan}

Agama berbicara tentang perdamaian. Sayangnya, itu sering menjadi sumber konflik yang signifikan antara para pengikutnya. Ketika penganut agama tidak menjalin kontak baik satu sama lain, cara berekspresi menjadi sedikit penting. Tetapi, ketika kontak di antara para penganut agama meningkat, komunikasi yang menciptakan perjumpaan, berbagai cara ekspresi dan interpretasi dipertanyakan. Realitas keanekaragaman membawa masalah hubungan dengan yang lain, lebih eksplisit, ini berbicara tentang persoalan kedamaian.

Selama beberapa dekade terakhir agama-agama telah terlibat dalam dialog. Namun meskipun upaya dialog dilakukan, masih ada saja masalah terkait dengan dialog. Analisis studi pendekatan yang telah dilakukan dalam eksklusivisme, inklusivisme, dan pluralisme juga belum cukup menjelaskan keragaman dalam membantu pemahaman demi terwujudnya kedamaian relasi antaragama.

Meskipun dalam studi terhadap pluralisme telah memberi terobosan pemahaman mengenai persoalan paradigma sebelumnya (eksklusivisme dan inklusivisme), namun perlu dipertimbangkan juga terdapat bahaya dalam pendekatan pluralisme ini, di antaranya: Pertama, tidak serius menanggapi persoalan identitas religius pribadi. Kedua, relativisme; dengan pengingkaran klaim kebenaran pribadi demi "bergaul" dengan yang lain; dan bahaya tidak benarbenar memahami dan memaknai komunikasi dengan "yang lain" hanya karena semua bertemu dalam kenyataan yang sama. Dialog interreligius tidak mungkin dijalankan dalam kerapuhan dan keragu-raguan mengenai iman seperti ini. Integritas sungguh dituntut dalam sebuah dialog.

Studi ini bermaksud untuk menunjukkan relasi interreligius tidaklah cukup dengan paham pluralisme; interreligius memerlukan integritas yang kuat sebagai akar agama sebelum berdialog —dan terbuka adalah asas yang membuka pintu ke jantung perdamaian bagi relasi beragama.

\section{Memahami Pluralitas: Sekelumit Dialog Pluri-Religius}

Desakan Konsili Vatikan II mengajak umat beriman untuk beralih dari model teologi yang mengagungkan kemapanan rumusan-rumusan dogmatis metafisis yang cenderung tidak 
menyentuh kehidupan manusia, kepada refleksi yang bertolak dari pengalaman konkret eksistensial fenomenologis. Menurut Edmund Husserl, fenomenologi berarti ilmu tentang esensi, mendesak pencarian esensi dalam nomenon. Sementara itu, eksistensialisme mengajukan pengalaman manusia sebagai yang bereksistensi. Manusia dipahami tampil, hadir, dan mengalami keseharian hidupnya. Eksistensialisme diawali oleh Soren Kierkegaard. Nietzsche juga termasuk dalam bilangan promotor eksistensialisme. Heidegger, salah satu filsuf yang amat berpengaruh pada Karl Rahner SJ juga mengatakan fenomenologi memiliki tema-tema sentral yang sangat penting. Idenya tentang lifeworld (dunia-hidup-keseharian) menjadi salah satu yang penting. Memaksudkan kurang lebih persis dengan apa yang disebut oleh Alfred Schutz sebagai everyday life; artinya, keseluruhan dari ruang lingkup hidup, relasirelasi dan peristiwa-peristiwa di sekitar saya (Riyanto, 2014: 225). Oleh sebab relasi-relasi dalam lifeworld ikut memengaruhi kehidupan seseorang, menjadi lalai jika pemahaman dialog dianggap tidak penting dalam berteologi kontekstual dan (inter)kontekstual, interkultural, ataupun interreligius.

Edward J. Gratsch (1981: 19-27), Karl Rahner (1969: 233-240), Hans Kung (1980: 1-12) sepakat bahwa inspirasi definitif saat munculnya teologi dialog menemukan titik awalnya sejak Konsili Vatikan II (1962-1965) yang menegaskan pentingnya refleksi teologis dengan beranjak dari kenyataan konkret, dari pengalaman. Dalam konteks Asia, kebutuhan untuk menggalang dialog interreligius amat mendesak. Sebab Gereja Asia berhadapan langsung dengan tantangan pluralitas di segala bidang kehidupan, termasuk yang amat menyolok adalah pluralisme agama dan kultur. Rahner menengarai perdebatan mengenai kutukan akan perbedaan pada masa sebelum Konsili Vatikan II, ia menegaskan perlunya pengembangan sikap-sikap toleransi timbal balik, kesediaan untuk saling memengaruhi dan dipengaruhi dan memupuk sikap-sikap kritis (Riyanto, 2014: 226-229).

Terkait dialog, Raimundo Panikkar mengatakan dalam relasi dengan yang lain, ada tiga kemungkinan sikap yang ditampilkan agama bila mengalami pertemuan. Sikap pertama adalah eksklusif, sikap menutup diri; menolak segala sesuatu yang bertentangan dengan kebenaran yang diyakininya dan mengklaim diri sebagai satu-satunya yang pemilik kebenaran; tidak memberikan tempat pada toleransi. Sikap kedua adalah inklusif, sikap memberi bagi toleransi dan segala sesuatu yang bertentangan dengan sikap pertama dan menegaskan diri sebagai pemilik kebenaran universal; bertindak bagaikan payung yang menaungi, mengakui, dan menghargai. Sikap ketiga, Panikkar menyebutnya paralelis atau pluralis, sikap menjaga batasbatas yang jelas dan di pihak lain menampilkan pembaharuan-pembaharuan yang konstan dari suatu agama (Panikkar, 1978: 13-19).

Berbicara tentang paralelis atau pluralis, artinya bahwa agama-agama yang berbeda merupakan jalan bagi keselamatan yang sama validnya untuk satu tujuan. Dalam wawasan 
ini agama-agama mengarahkan para pengikutnya ke realitas pokok dan mengukuhkannya sebagai kesamaan dengan yang lain dan dianggap benar dan pada dasarnya setara. Dengan kata lain semua agama sama, posisi agama dan tradisi dalam kasus ini tidak seperti terpisah dan diunggulkan seperti dalam eksklusivisme dan inklusivisme. Dalam pluralis, semua platform sama dan semua bertemu dengan rasa kesetaraan. Hick jelas bereaksi terhadap pendekatan eksklusif dan inklusif dalam konteks keragaman agama ini, ada kritik terhadap Extra ecclesiam mulla salus, "Di luar gereja tidak ada keselamatan". Ia mengakui bahwajika hal ini diterima, gereja akan menyangkal penyelamatan Allah bagi mereka yang berada di luar agama Kristen. Dan jika memang demikian maka yang akan terjadi adalah bahwa keselamatan yang dimungkinkan di dalam kekristenan, tidak mungkin terjadi di luarnya. Hick tidak menerima hal ini sebab baginya ini mengasumsikan bahwa pengeksklusifan keselamatan seperti ini mensyaratkan bahwa sebagian besar umat manusia di sepanjang sejarah belum diselamatkan dan ini sudah cukup menjelaskan pendiskreditan sebuah hermeneutik soteriologi. Hick yakin bahwa keselamatan terjadi tidak hanya di dalam agama Kristen tetapi juga dalam agama-agama besar lainnya di dunia. la menyebut hal ini, "agama-agama besar dunia adalah cara kebenaran yang dipakai dalam keselamatan". Hick menganjurkan bahwa tradisi agama besar dunia, sekarang perlu mengubah pengikut mereka dari fokus mementingkan diri sendiri kepada fokus dan berpusat pada realitas. Orang-orang beriman dari setiap agama besar membuka pikiran mereka ke realitas yang lebih tinggi dalam kehidupan bersama. Dalam penjelasannya tentang eksistensi variasi agama-agama yang berbeda, Hick mengatakan: Manusia merespon pada realitas yang sama, "kebenaran":

\footnotetext{
"Kita selalu memandang yang transenden melalui lensa budaya religius tertentu dengan serangkaian konsepnya yang khas, contoh-contoh mitos dan sejarah, liturgi kebaktian dan meditasi. Sebuah kontribusi manusia yang tidak dapat dipungkiri, terhadap kesadaran beragama inilah yang menyebabkan variasi agama yang menakjubkan."
}

Sebagaimana yang telah kita lihat dalam pemikiran Hick ini, ada persoalan utama bagi semua agama besar dunia dan pengalaman beragama itu sendiri. la menjelaskan argumen ini dengan mengacu pada perbedaan Kantian antara nomenon dan fenomena dalam epistemologi persepsi. Pembedaan ini menunjukkan bahwa ada persoalan keutamaan agama di dalamnya (sebuah kebenaran) seperti yang dialami orang-orang yang terkondisi secara historis dan budaya. Hick menyebutnya sebagai "kebenaran". Kebenaran ini tidak pernah menjadi objek yang nyata dalam pengalaman religius. Kebenaran ini dialami oleh manusia yang terbatas dalam latar belakang budaya dan sejarah di mana mereka tumbuh. Dengan kata lain, kebenaran tergantung pada budaya di mana seorang individu tumbuh, ia dapat mengalami yang benar sebagai Pribadi, yaitu: Yahweh, Allah, Krishna, atau non-pribadi, seperti: Dharmakaya, Sunyata, 
Nirguna Brahman. Meskipun semua agama besar dunia adalah respons yang beragam terhadap kebenaran yang sama, tidak semua respon dan persepsi akan kebenaran memiliki nilai yang sama, "Beberapa memediasi Tuhan bagi umat manusia lebih baik dari yang lain". Oleh karena itu jika ada kriteria untuk menilai agama, ia mengatakan bahwa kriteria dasar haruslah berfokus pada soteriologi atau tentang keselamatan. Dalam pandangan ini, tradisi keagamaan "memiliki nilai yang lebih besar atau lebih kecil sesuai bagaimana mereka memperkenalkan transformasi dari keselamatan itu sendiri." Atau dengan kata lain bagaimana mereka memediasinya. Ini menjelaskan bahwa beragam agama di dunia harus ditegaskan sebagai alternatif religius yang sama-sama sah yang mengarahkan penganutnya ke Kebenaran Tertinggi. Pendekatan ini menunjukkan bahwa semua agama besar di dunia dianggap benar secara formal dan pada dasarnya sama, semua agama besar sama-sama memiliki jalan keselamatan yang sama untuk memperoleh keselamatan. Ini nantinya yang akan menghantar pada kesadaran bahwa pendekatan pluralitas semacam Hick ini cenderung menghilangkan keunikan dan kekhasan masing-masing agama perlu untuk didiskusikan ulang.

Selain Hick, juga ada teolog lain yang berbicara mengenai jalan ke tujuan yang sama. Jacques Dupuis, seorang teolog di India yang berbicara situasi dialog yang memaksa seseorang untuk melampaui keberpusatan pada Gereja. Baginya, "Signifikansi penyelamatan dalam tradisi keagamaan umat manusia, tidak boleh dipusatkan hanya dalam hubungannya dengan Gereja, tetapi Kristus, yang misteri-Nya terbuka kepada berbagai cara mediasi bahkan jika berbeda sekalipun." Dalam pengertian yang lebih luas, ini adalah keyakinan bahwa tidak ada satu agama pun yang memonopoli kebenaran yang membawa pada keselamatan. Atau dalam kata-kata yang lebih puitis dari tokoh Sufi, Rumi, yang berbicara tentang agama-agama dunia, seperti "Pelita-pelita berbeda tetapi cahaya sama; cahaya itu beyond". Ayat Al-Quran yang terkenal:

\footnotetext{
“Jika Tuhan berkenan Dia pasti akan membuat anda menjadi satu (mengaku dalam satu iman). Namun, la ingin mencoba dan menguji anda dengan apa yang Dia telah berikan kepada anda. Jadi cobalah untuk unggul dalam perbuatan baik. Bagi-Nya, anda semua akan kembali pada akhirnya, saat la memberi tahu anda tentang perbedaan anda" (5:48).
}

Banyak ayat dalam Al-Quran mendukung tanpa membedakan penyataan para nabi selama berabad-abad. Namun pengembangan literatur masing-masing agama untuk pemahaman yang lebih luas hanya dapat dilakukan di dalam keyakinannya dengan persyaratannya sendiri dan oleh penganutnya sendiri. Dan itu perlu dilakukan pada skala yang semakin meningkat. Namun demikian, pluralisme menemukan kritik terhadapnya. Pluralisme selain telah membangkitkan paradigma-paradigma dalam berteologi, juga menciptakan krisiskrisis baru. Krisis baru ini pada prinsipnya bertumpu pada persoalan hermeneutika tentang 
hubungan antara tradisi dan situasi dewasa ini, dan keanekaragaman penafsiran yang relatif. Kritik pluralisme juga meliputi persoalan validitas kejujuran intelektual, ini sejalan dengan beberapa persoalan perbedaan antara agama-agama besar dunia, beberapa perbedaan antara berbagai agama tidak dapat didamaikan dengan cara seperti "keduanya-dan". Mereka jelas bertentangan. Kontradiksi ini tidak membantu dalam dialog yang didasarkan pada kebenaran yang ada dalam tradisi agama masing-masing. Kritik yang sangat penting adalah bahwa pluralisme mengesampingkan keyakinan utama agama, seperti Kristen: Bahwa Yesus Kristus adalah Wahyu Allah yang unik. Hal yang sama dapat dikatakan pada sisi Islam yang membawa keyakinan Islam: Bahwa Al-Quran adalah Wahyu unik dari Tuhan. Pendekatan pluralis memahami "pluralitas agama-agama" sedemikian rupa, sehingga Knitter mengatakan bahwa mereka "tidak menganggap serius Pluralitas dan karena itu kehilangan perbedaan yang tidak dapat dihindarkan di antara agama-agama, atau mereka begitu tersapu oleh keinginan untuk berdialog dan rukun namun mereka mengabaikan atau mengecilkan apa yang unik dari setiap agama". Jika Knitter membandingkan pluralitas dengan orkestra maka Knitter menunjukkan bahwa pluralis "terpesona oleh keindahan simfoni, pluralis kehilangan kekhasan masing-masing instrumen musiknya” (Philips, 2013: 8).

Tanpa meninggalkan kritik terhadap pluralis di atas, sekarang kita masuk pada upaya memahami interreligius. Secara terminologis, tidak ada definisi tunggal mengenai interreligius, karena adanya keberadaan agama lain. Namun, definisi yang dapat mendukung tulisan ini, ide-ide dari beberapa pemikir interreligius akan dipertimbangkan. Harvey Cox menegaskan dalam melakukan dialog interreligius dengan menyembunyikan identitas setiap pihak; atau tidak mempertimbangkan keunikan masing-masing, maka itu bukan dialog interreligius, tidak ada bedanya dengan dialog umum (Lie, 1998: 8). Leonard Swidle menyebut interreligius (interiman) merupakan percakapan antara individu-individu dan melalui mereka, dua atau lebih komunitas atau kelompok-dengan perbedaan pemahaman kepercayaan-dapat belajar dari yang lain sehingga ia diubah dan tumbuh (Swidler, 1987: 21). Dialog interreligius adalah untuk mendapatkan manfaat dari pemahaman yang lebih baik tentang tradisi, ajaran, dan pandangan lain tentang realita dan pemahaman akan kebenaran. Pertanyaan dan jawaban umum di antara agama-agama tertentu diyakini dapat memperkaya masing-masing tradisi. Meskipun ada kontradiksi, perbedaan dan pengecualian, mereka terlibat dalam pencarian bersama, saling melengkapi dan inklusif di antara mereka. Tujuan umum ini untuk menjawab kondisi yang diperlukan bagi keberagaman.

David Tracy yang selaras dengan Swidler, menunjukkan tidak masalah apakah dialog itu dilakukan antara "pribadi ke pribadi" atau melalui dialog tulisan serius tentang teks, ritual atau sebuah peristiwa. Tujuan utamanya adalah mengenali yang lain sebagai "yang lain", yang berbeda sebagai yang berbeda dan untuk mengakui "bahwa makna dari dunia yang lain, dalam 
beberapa hal, adalah opsi yang mungkin untuk saya". Gagasan Tracy tentang dialog interreligius adalah seperti sebuah kendaraan untuk menciptakan "opsi yang memungkinkan" bagi para mitra dialog dengan respek pada pergeseran makna, interpretasi, dan pada akhirnya kesadaran religius. Mitra dialog dipandang sebagai agen yang diperlukan untuk membawa perubahan dalam pertumbuhan agama sendiri atau transformasi tradisi agama sendiri (Tracy, 1990: 41).

John Cobb menantang para penganut agama untuk mendengar sebuah otentisitas kebenaran yang diajarkan dalam agama lain dan ditransformasikan. la mengatakan bahwa penganut agama harus mengambil kesempatan untuk berdialog secara terbuka satu sama lain, tidak dengan tujuan menemukan sesuatu yang sama, atau mengalahkan yang lain dalam perdebatan, tetapi dengan tujuan yang masing-masing ditantang oleh wawasan dari "yang lain" sehingga sebuah konsensus baru dapat muncul yang didasari sesuai dengan komitmen semua pihak. Dialog interreligius melampaui "bentuk-bentuk" dan "aturan formal" apa yang disebut Seyyed Hossein Nasr "kediaman kedamaian" yang melampaui perbedaan formal dan dalam terang dari realitas berguna untuk mendapatkan pemahaman yang lebih simpatik tentang mengapa ada perbedaan yang tidak dapat direduksi antara penganut agama yang berbeda secara formal (Philips, 2013: 9). Namun ini dilakukan dengan keunikan dari agama masingmasing dan sebagai bentuk penghormatan terhadap tradisi sakral satu sama lain dalam proses dialog yang dilakukan. Pertemuan antarumat beragama di dunia tidak dapat disangkal telah merobek tabir eksklusifisme agama. Agama-agama mulai mengembangkan sikap keterbukaan. Mereka mulai berusaha hidup berdampingan dan menjalin kerja sama.

\section{Indonesia sebagai Konteks Berdialog Interreligius}

Sebuah negara yang memiliki keanekaragaman sebagai bagian integral dari tata riasnya dapat menyesuaikan diri dengan perbedaan-perbedaan yang ada. Etika dunia yang umum telah menemukan jalannya dalam etos bersama. Indonesia yang didasari oleh Pancasila, memungkinkan masyarakatnya untuk kembali ke asas semula, untuk menemukan karakterkarakter agama mereka masing-masing.

Aspek interreligius Pancasila diperlihatkan pada nilai-nilai ketuhanan yang dikehendaki Pancasila, yaitu nilai-nilai ketuhanan yang positif, yang digali dari nilai-nilai profetis agamaagama yang bersifat inklusif, membebaskan, memuliakan keadilan, dan persaudaraan. Ketuhanan yang lapang dan toleran memberikan semangat kegotongroyongan dalam rangka pengisian etika sosial agama-agama dalam kehidupan berbangsa dan bernegara. Ketuhanan Yang Maha Esa tidak lagi hanya dasar hormat-menghormati agama, melainkan menjadi dasar yang memimpin ke jalan kebenaran, keadilan, kebaikan, kejujuran, dan persaudaraan. Berdasarkan kenyataan ini, sila Ketuhanan Yang Maha Esa menjadikan Indonesia bukanlah 
negara yang terpisah dari agama. Secara lazim dikatakan, "Indonesia bukan 'negara sekuler' dan bukan juga 'negara agama'." Ketuhanan yang sejalanan dengan kemanusiaan, persatuan, keadilan, dan kemufakatan, merupakan solusi terbaik bagi keragaman. Di dalam Pancasila ada simbiosis (tanpa saling mengucilkan dan saling mengalahkan), sekaligus sikap kritis pada fundamentalisme agama dan fundamentalisme sekuler. Dari sinilah Pancasila dengan ketuhanan yang berkebudayaan yang terbuka dan toleran merupakan sebuah hermeneutik interreligiusitas yang sehat. T.B. Simatupang pernah merefleksikan Pancasila demikian, "The five (Pancasila) are a wide enough umbrella for everybody. No body has anything against them, people can accept them, we can all live together under them" (Kelima Pancasila sudah cukup memayungi setiap orang. Tidak ada yang menentangnya, semua dapat menerimanya, kita dapat hidup bersama di bawahnya) (Pattipeilohy, 2018: 130).

Senada dengan hal ini, menurut Eka Darmaputera percakapan tentang Pancasila sudah merupakan titik temu yang bersifat aktif. Mengapa? Pertama, Pancasila merupakan pilihan satu-satunya bagi integrasi masyarakat Indonesia, oleh karena ia berakar pada "kebudayaan bersama" masyarakat Indonesia, dan tidak sekadar merefleksikan salah satu dari beberapa lapisan budaya yang ada. Di dalam Pancasila semua lapisan budaya melihat diri mereka tercermin di dalamnya. Kedua, Pancasila diterima karena ia memberi ruang kepada semua pihak untuk masing-masing menyumbangkan apa yang dimilikinya bagi kepentingan seluruh masyarakat dan bangsa, sesuai dengan identitas masing-masing. Semua diperlakukan sama dalam hak dan kewajiban. Di dalam Pancasila, tidak ada mayoritas dan minoritas. Semua adalah peserta penuh. Dan ketiga, Pancasila mampu melahirkan "aturan permainan" (modus vivendi) yang dapat mencegah potensi-potensi perpecahan menjadi kenyataan lewat "conflict management" yang cerdik dan hampir-hampir unik. Lewat pendekatan yang nondiskriminatif, ia memberikan suatu kerangka di mana semua kelompok di dalam masyarakat dapat hidup bersama, bekerja bersama di dalam suatu "dialog kerja" yang terus-menerus guna membangun suatu masyarakat masa depan bersama, masing-masing bertolak dari kepercayaan dan keyakinannya (Pattipeilohy, 2018: 131-134).

Bernard Adeney berkata tentang "Ketuhanan yang Berbhineka Tunggal Ika" yang memperjelas model interreligiusitas yang mewakili semua pengalaman agama-agama di Indonesia dalam membangun titik temu. Menurut Adeney, telah banyak upaya untuk menjelaskan keindonesiaan kita dengan mempertahankan ke-bhinekatunggalika-an secara bersama-sama. Usaha pertama, monisme, namun cenderung menolak kebhinekaan. Kedua, politheisme, namun cenderung menolak ke-ika-an. Usaha ketiga, monotheisme terbuka. Di sini baik Kristen dan Islam termasuk di dalamnya, namun terbuka pada paham ketuhanan agama lain. Dalam Islam, Allah adalah satu dan dunia adalah beraneka ragam. Kristen setuju dengan hal ini. Tetapi Kristen juga sekaligus menyatakan bahwa Allah Trinitaris dan dunia adalah satu. 
Atau, Allah adalah Bhineka Tunggal Ika dan oleh karena itu, dunia ini juga Bhineka Tunggal Ika. Dalam konsep Allah Tritunggal diberi ruang yang seimbang dan sama-sama dipelihara antara kebhinekaan dan keikaan yang penting bagi keindonesiaan kini dan di masa depan. Inilah gagasan ketuhanan yang sekali lagi harus disebut sebagai ketuhanan hasil pertemuan yang saling memperkaya di antara kebudayaan-kebudayaan dan agama-agama yang ada di Indonesia. Lebih lanjut, agama-agama yang terlibat dalam tafsir Pancasila umumnya sepakat bahwa konsep ketuhanan dalam sila pertama Pancasila mengandung kolektivitas yang memberikan arti bahwa kita tidak pernah bertuhan sendirian. Karena bertuhan berarti harus memelihara solidaritas antarmanusia, antara lain dalam memperjuangkan pembebasan dari ketidakadilan dan penderitaan manusia lain dan alam. Titik masuknya seperti kata Gerrit Singgih, yaitu dari iman kepada Roh Kudus yang tidak terbatas pada gereja atau orang-orang Kristen dan bekerja seluas semesta ini. Roh Kudus yang karya-Nya ada pada semua agama dan kebudayaan. Kesemua konsep itu memperlihatkan tentang Allah yang berdialog terus dengan diri-Nya untuk menata Indonesia ini menjadi lebih baik dan adil (Pattipeilohy, 2018: 132). Untuk lebih memahami apa yang dimaksudkan Gerrit Singgih, Ubiquitas Roh Allah dalam pemikiran Tillich dan Samartha, Kristologi Teosentris John Hick, dan dialog sebagai sarana pendalaman iman dari R. Panikkar yang dapat membantu kekristenan terkhususnya, dalam upaya berdialog dengan agama-agama di Indonesia dalam upaya berteologi interreligius yang terbuka.

Pertama, Ubiquitas Roh Allah (Paul Tillich; S.J. Samartha) (Tillich, 1951: 273). Dengan ubiquitas Roh Kudus, dimaksudkan kehadiran Roh Kudus di mana-mana. Karya Roh Kudus tak bisa dikurung dan dibatasi dalam agama tertentu. Paul Johannes Tillich (1886-1965) adalah seorang teolog Protestan Jerman-Amerika dan seorang filsuf eksistensial. Tillich ingin melindungi transendensi Allah. Ia mengatakan bahwa tindakan Allah melalui Roh-Nya tak mungkin dimonopoli dalam satu agama. Agama Kristen pun tidak. Allah bebas hadir dan berkarya di mana-mana. Bahkan la dapat berkarya pada apa yang bukan atau belum merupakan agama. Yang dimaksud quasi agama ialah bukan agama tetapi memiliki keserupaan identitas untuk disebut sebagai agama. Yang bukan agama ini dapat berupa ideologi, kepercayaan tradisional, aneka tradisi religius yang lain. Dalam apa yang tampak tidak ada sangkut-pautnya dengan agama ini. Allah melalui Roh-Nya yang bertindak. Transendensi Allah melingkupi dan mengatasi segala-galanya.

Gagasan mengenai ubiquitas Roh Allah ini dikatakannya sebagai yang dapat mencegah eksklusivisme dan partikularisme dalam kekristenan, sekaligus dapat merangkul agama-agama lain yang dalam kenyataannya juga mengalirkan bentuk-bentuk kebaikan dan penebusan. Dalam pengamatan Tillich agama Kristen terjebak dalam ketegangan antara partikularisme dan universalisme. Yang partikularisme tampak menonjol dalam pengakuan akan Yesus dari Nazareth sebagai Kristus, pemenuhan penyataan Allah. Dan inilah yang paling sering 
dikatakan sebagai kriteria untuk seluruh perjumpaan agama Kristen dengan agama-agama lain dan untuk penilaian diri dari orang Kristen. Dalam konteks dialog, kriteria ini menurut Tillich sulit untuk dapat dipertahankan. Dalam dialog, kriteria harus pula didasarkan pada apa yang dapat didialogkan. Pengakuan akan transendensi Allah dan gerak Roh-Nya yang tak terbatas merupakan salah satu wujud kriteria yang bersifat dialogis, dalam kedalaman dari suatu agama, Tillich menegaskan, ada satu titik di mana partikularisme menerobos kebebasan rohani dan ke satu visi mengenai kehadiran ilahi dalam ungkapan-ungkapan lain yang tak dapat dibatasi pada satu struktur atau lembaga agama.

Stanley J. Samartha (1990), yang juga seorang teolog Protestan, senada dengan Tillich, menekankan pula karya Roh Kudus di mana-mana. Dalam artikelnya The Holy Spirit and People of Other Faiths, Samartha menegaskan bahwa dalam kondisi pluri-religius dunia saat ini ekonomi keselamatan tidak bisa lagi direduksi dalam ekomoni keselamatan seperti yang dipikirkan oleh iman Kristen. Umat Kristen harus dapat mentransendensikan sejarah keselamatan yang diimaninya terpenuhi dalam diri Kristus. Sejarah keselamatan tidak dapat disempitkan hanya dalam iman akan Kristus yang eksklusif. Untuk itu, seorang Kristen perlu menyadari dan mengakui bahwa Roh Kudus berkarya di mana-mana. Aneka gerakan pembebasan, kekuatan cinta dan kebijaksanaan politik yang mengedepankan penghormatan terhadap martabat pribadi manusia, harus dapat diyakini oleh orang-orang Kristen sebagai gerak karya Roh Kudus biar pun itu berlangsung di luar batas-batas Gereja atau lingkungan Kristen. Kesadaran teologis yang menekankan teosentris lewat karya Roh Kudus-Nya di manamana menyumbang pergumulan yang dapat membebaskan agama Kristen dari kungkungan eksklusivisme.

Kedua, Kristologi Teosentris (John Hick) (Hick, 1972: 98-138). Diakui bahwa persoalan pokok dalam dialog interreligius itu langsung menyentuh problem keunikan Kristus. Lucient Richard (1981) melukiskan persoalan itu dengan tajam: “Dapatkah agama Kristen menerima agama-agama lain sebagai jalan absah menuju keselamatan tanpa meninggalkan keyakinannya dan memutlakkan keunikan Kristus?" Apakah mungkin untuk percaya bahwa di satu pihak Allah telah bertindak secara definitif untuk keselamatan semua orang di dalam Kristus dan di lain pihak sekaligus harus percaya bahwa orang Islam, Hindu, Buddha, dan Yahudi dijamin untuk tetap pada keyakinan agama mereka dan mengikuti jalan mereka sendiri yang berbeda dapat menuju keselamatan?

Bila persoalan itu menyentuh keunikan Kristus maka secara langsung juga menyangkut keunikan (identitas) agama Kristen. Karl Rahner mencoba menembus problem rumit ini dengan mengajukan terminus yang sangat terkenal, Kristen anonim. Gagasan ini mau menegaskan bahwa yang memeluk agama-agama lain tetap ada dalam kawasan Kristen. Hanya karena mereka tidak tahu, tidak akan sadar akan "kekristenannya", mereka disebut anonim. Dengan 
ini, keselamatan tetap tidak dilepaskan dari Kristus. Hampir serupa dengan gambaran Rahner (tetapi tidak sama), Hans Kung menyebut mereka (pemeluk agama-agama lain) sebagai Kristen in spe (dalam pengharapan); sementara itu orang-orang Kristen disebutnya sebagai Kristen in re (dalam kenyataan konkret). Namun pandangan ini, menurut John Hick, masih merupakan pandangan yang kristosentris. la mengkritik pandangan ini sebagai cara yang dapat memberikan pemecahan psikologis terhadap eksklusivisme masa lampau yang berakar pada kristologi tradisional, tetapi gagal secara teologis untuk memberi jalan keluar bagi arus inklusivisme dewasa ini. John Harwood Hick (1984), seorang teolog Presbiterian (Anglikan), mencoba menyumbang pemecahan dengan pergumulan kristologi teosentris. la hendak mencari pemecahan jalan, kebenaran, dan kehidupan. Dan gagasan ini dapat menjadi jembatan bagis usaha-usaha untuk menjalin suatu dialog interreligius.

Ketiga, dialog sebagai sarana pendalaman iman (R. Panikkar) (Riyanto, 2014: 299301). Sebagaimana Samartha, Raimundo Panikkar, seorang teolog Katolik, tidak berminat dengan upaya-upaya membangun teologi universal di atas dasar yang netral (John Hick, W.C. Smith, Leonard Swidler). Dalam tulisannya, The Invisible Harmony: A Universal Theory of the Religion or a Cosmic Confidence in Reality, ia memeriksa bahwa upaya merekayasa teologi universal lebih banyak merupakan buah traumatis dunia penelitian Barat. Dalam penelitian dunia Barat, kerap diyakini proposisi bahwa bila sesuatu tidak universal, proposisi tersebut tidak sahih. Padahal dialog lebih merupakan bentuk budaya yang banyak mengalir dari alam dunia Timur yang mengedepankan harmoni dengan membiarkan partikularitas. Suatu dialog, menurutnya, bukanlah hubungan asimilasi (hubungan yang mencari penyelarasanpenyelarasan universal) atau hubungan substitusi (hubungan yang bersifat mengganti) atau disebut pula-dengan nama keliru-hubungan konversi (yang mempertobatkan), melainkan hubungan saling menyuburkan atau saling mengantar kepada pendalaman pengalaman iman masing-masing. Karena pengertian yang demikian, Panikkar mengajukan tesis bahwa melalui dialog pengalaman-pengalaman partikular mengenai kebenaran (pengalaman akan Kristus bagi orang Kristen atau Veda bagi orang Hindu) dapat diperluas dan diperdalam sehingga orang makin terbuka akan pengalaman-pengalaman baru mengenai kebenaran.

Dalam konteks Indonesia yang pluri-religius ini, tujuan dialog ialah menemukan kedalaman pengalaman iman dalam komunitas-komunitas religius yang berbeda-beda. Di sinilah letak perbedaan Panikkar dan Samartha. Jika Samartha lebih menekankan kerja sama membangun kesejahteraan masyarakat dan membiarkan kepelbagaian keyakinan kebenaran, maka Panikkar melangkah maju kepada pendalaman iman. Dialog harus merupakan sharing pengalaman iman. Bagaimana suatu sharing pengalaman iman ini dijalankan? Panikkar mengusulkan tiga syarat sekurang-kurangnya sebagai jalan untuk masuk ke dialog sebagai sharing. Pertama, kita harus dapat menempatkan agama kita dalam suatu tatanan (atau 
sistem pandangan) sebenarnya dan itu berarti tidak seperti kenyataan yang ada saat ini. Kedua, kita harus bersikap terbuka terhadap yang lain. Ketiga, kita harus menyimak pengalaman keseluruhan manusia. Di balik seluruh dialog ada misteri ilahi yang penjelasannya diusahakan oleh setiap agama. Misteri ini bukanlah realitas ilahi dan kosmis (merangkum seluruh alam ciptaan). Lambang yang pada umumnya bersifat netral, seperti Allah, Roh atau Kebenaran, ditolak oleh Panikkar, karena memenggal realitas dan membatasi misteri ilahi pada suatu prinsip yang tidak penting, suatu penampakan ilahi yang tidak historis, dan berhenti hanya pada suatu abstraksi. Dalam bukunya, The Trinity and the Religious Experience of Man, Panikkar mengakui bahwa pertemuan agama-agama hanya dapat berlangsung pada inti tradisi-tradisi agama itu sendiri, dan bagi orang Kristen itu adalah pengalaman mengenai Trinitaris. Bagi Panikkar, Trinitas merupakan suatu persimpangan jalan di mana dimensi-dimensi rohani yang otentik dan khas bertemu dalam sebuah relasi dialog, hal ini tentu membantu kekristenan pada relasi dialog interreligius di Indonesia.

\section{Open Integrity: Sebuah Pendekatan Dialog Interreligius yang Bergerak Beyond Pluralism}

Harus diakui dalam dialog interreligius tidaklah gampang. Hambatan yang "rutin" hadir dalam proses dialog ini seperti tidak cukupnya dasar kemantapan kepercayaan seseorang, tidak cukupnya pemahaman dan pengetahuan tentang agama-agama lain secara benar dan seimbang, yang menyebabkan kurangnya penghargaan sekaligus dengan gampang muncul sikap-sikap curiga yang berlebihan, perbedaan kebudayaan karena tingkat pendidikan yang tidak sama; juga masalah bahasa yang sangat peka dalam kelompok-kelompok tertentu, faktor-faktor sosial-politik dan beban ingatan sejarah traumatis, pemahaman yang salah mengenai beberapa istilah yang biasa muncul dalam dialog, misalnya: pertobatan, pembaptisan, keselamatan, dll., merasa diri cukup atau sempurna yang menyebabkan sikap-sikap defensif dan agresif, kurang yakinnya terhadap nilai-nilai dialog interreligius, yang oleh beberapa orang dianggap sebagai suatu tugas khusus para ahli dan dianggap sebagai tanda kelemahan, pengingkaran iman, dan sebagainya. Hambatan-hambatan ini perlu diterangkan terus-menerus.

Ajaran tentang dialog interreligius dari dokumen-dokumen sejak Ecclesiam Suam (1964) sampai Dialogue and Proclamation (1991) barangkali lebih menampilkan ciri afirmatif (menegaskan) dan imperatif (mendesak) daripada negatif (melarang, memagari) sehubungan dengan pengembangan teologi dialog. Hal ini menjadi realitas yang kompleks, kenyataan kompleksitasnya tidak hanya menyentuh alasan pluralisme agama, melainkan juga sering kali menyangkut situasi dan kondisi setempatnya yang khas. Dialogitas dalam agama merupakan gebrakan baru. Refleksi teologis dialogal menyeruak dan membongkar cara-cara lama dalam 
berteologi. Perspektif ini bukan hanya merevisi paradigma teologi tradisional, melainkan juga menampilkan kemungkinan baru yang lebih dialogal dalam menghayati dan mengomunikasikan kebenaran-kebenaran iman. Dengan ciri transormatif dialogal semacam ini, dapat membongkar teologi tradisional yang bercirikan eksplanatoris (menjelaskan rumusan-rumusan kebenaran iman), verifikatif (membuktikan kebenarannya), apologetis (membela dan melindungi rumusannya), dan eksklusif (menyisihkan aneka kemungkinan perumusan lain) (Banawiratma SJ, 1991: 11).

Namun dalam dialog interreligius ini tentu yang paling mendasar adalah kesadaran penuh akan integritas, perlunya sebuah integritas terbuka/open integrity yang bertujuan mendidik diri dalam memahami satu sama lain sehingga dapat menggambarkan dirinya sendiri. Dalam integritas ini tidak berarti sebuah agama harus menyetujui atau bahkan menyukai ideologi dan doktrin agama lain. Namun, memberi satu sama lain kesempatan untuk menggambarkan diri dengan istilahnya sendiri dan diharapkan dengan hal ini dapat mengenali diri dan apa yang dianutnya. Open/terbuka artinya pengakuan akan keunikan dan kebebasan beragama dalam dialog antara agama sendiri dan agama rekan. Menyumbangkan kekayaan keyakinan seseorang dan juga diperkaya. Pemahaman tentang klaim kebenaran agama sendiri dapat menginterpretasikannya, dan keterbukaan untuk rekan dialog menginterpretasikan agama mereka (Philips, 2013: 8). Integritas artinya, bahwa mereka yang telah dalam dialog yakin bahwa kepercayaan pada agama mereka sendiri adalah yang paling tepat bagi mereka dan itulah sebabnya mereka mengakuinya dengan sepenuh hati, berakar pada agama sendiri, dan masuk ke jantung agama sendiri, sementara juga dapat masuk ke jantung agama lain. Tidak ada cara untuk menolak kebenaran agama sendiri untuk mengerti kebenaran dari agama lain dalam sebuah dialog yang dilakukan.

Dengan kata lain open intergrity adalah untuk lebih memahami siapa kita, apa yang kita yakini sebagai Kristen, Islam, Buddha, Hindu, atau agama lainnya memiliki gagasan yang jelas tentang agama. Memang sangat mudah bagi para penganut untuk tidak berpikir dan melihat ke dalam tentang apa yang diyakini oleh agamanya sendiri, terutama jika seseorang tumbuh dalam komunitas yang seagama, tidak ada masalah, mengikuti apa saja yang diminta oleh agama sendiri dengan baik, tetapi kemudian, terkadang bila tiba pada perenungan untuk berpikir, apa sebenarnya yang saya yakini? Kepada siapa saya percaya? Bagaimana seseorang dapat menjelaskan ketika seorang bertanya tentang Tuhan? Ketika mitra dialog kita bertanya kepadanya "siapa Tuhan"? Ketika berpikir tentang kehidupan pribadi, kematian, dan surga, tentang keberadaan Tuhan terutama pada saat bencana, hal-hal ini membuat seseorang berhenti sejenak dan kemudian berpikir untuk melihat ke dalam.

Ketika para penganut yang berbeda melihat ikon-ikon Allah satu sama lain dan mendengarkan penjelasan satu sama lain, mereka berkata kepada dirinya sendiri, "Ajaranku 
tentang Tuhan tidak seperti itu", tetapi apa gagasan kita tentang Tuhan? Para penganut agama tertentu yang berdialog memberi peluang untuk menjalani "jeda" ini dengan sangat nyata. Tidak ada cara yang lebih baik untuk benar-benar memahami apa yang diyakini selain menjelaskan kepada orang lain. Dalam tindakan mengartikulasikan siapa dan apa yang diyakini, apa yang diperjuangkan dalam sebuah agama, setiap orang diberi kesempatan untuk masuk dalam keterlibatan yang mendalam dengan tradisinya masing-masing.

Hans Kung menegaskan keterlibatan mendalam dari tradisi keagamaan sendiri adalah satu-satunya pondasi nyata dari dialog antar agama dan menegaskan seseorang credible (dapat dipercaya) atau tidak. Jika hal ini tidak diperhatikan, seseorang tidak akan siap untuk bergerak, dan tidak akan benar-benar berpartisipasi dalam dialog antar agama sama sekali, ia hanya seperti seorang yang berpikir terbuka terhadap agama lain (plural), tapi bukan dialog antar agama. Pendekatan open integrity membuat seseorang lebih berakar dalam iman sendiri, dengan memahami dan berhubungan dengan iman orang lain (Philips, 2013: 236-238). Bagaimana pendekatan open integrity ini dapat diterjemahkan ke dalam praktik sehari-hari? Bagaimana setiap agama dapat berjumpa dengan baik dalam sebuah komunitas? Bagaimana setiap agama dapat mengembangkan cara yang lebih realistis dalam sebuah dialog yang mengarah pada kebebasan, rasa hormat dan kebenaran? Bisakah hal ini dapat terealisasi dalam dunia yang global saat ini?

Dalam dunia globalisasi saat ini, tentu dibutuhkan nilai-nilai etis, hak-hak sosial yang global, keadilan, dan setiap orang mempromosikan demokrasi yang lebih partisipatif dan berupaya menuju hubungan interkultur dan antar religius. Upaya ini dapat diterjemahkan sebagai bentuk: (1) Bergeser dari ruang sendiri ke perspektif global; (2) Pemikiran jangka pendek dan jangka panjang; (3) dari kesenjangan menjadi menjembatani; (4) Dari "alam untuk kita", menjadi "di dalam alam". Dengan hal ini, setiap orang dipanggil untuk perubahan paradigma baru dalam dialog, mencerahkan hati dan pikiran demi menciptakan ruang bagi setiap agama. Dialog yang dilakukan memiliki karakteristik: Pertama, keterbukaan. Di mana pembelajaran terjadi dan membiarkan proses belajar-mengajar yang mentransformasi. Keterbukaan lebih dari sebuah ruang. Menciptakan ruang berarti menghilangkan halangan untuk belajar, menangguhkan kecenderungan terhadap diri sendiri. Namun keterbukaan yang dimaksud membawa pada karakter kedua, yaitu batasan-batasan. Dalam hal ini, batasan menjadi 'alarm' yang baik bagi jalannya dialog. Sebab tanpa batasan dalam hal berdialog, dialog tidak akan membawa kita pada kebaikan bersama dan menciptakan kebingungan dan kekacauan. Sebab dalam situasi ini sering terjadi ketidaknyamanan dan rasa sakit, tak jarang membawa pada tindakan yang membawa pada kekacauan yang lebih buruk daripada kedamaian. Kedamaian adalah kecerdasan hati dan penting untuk disadari di sini bahwa rasa sakit dan ketidaknyamanan merupakan indikasi bahwa kebenaran sedang berjuang untuk dilahirkan di dalam dan di antara dialog umat beragama. 
Kung menguraikan gagasan batas ini dengan penjelasan bahwa tidak ada nilai yang berharga dalam agama-agama lain yang harus disangkal, tetapi juga tidak ada sesuatu pun yang tidak diterima secara kritis. Ini berbicara tentang dialog yang harus kritis, di mana semua agama ditantang bukan hanya untuk membenarkan segala sesuatu tetapi menyusun pesan mendalam dan terbaik bagi dialog. Sebab dialog haruslah menjadi tanggung jawab bersama dan kesadaran bahwa tidak ada satu agama pun memiliki kebenaran yang "readymade", tetapi "semua berada di jalan menuju kebenaran yang lebih besar". Ketiga, keramahan. Karena dalam dialog menjadi tempat belajar-mengajar, sering menjadi tempat yang menyakitkan, setiap agama harus memiliki karakteristik keramahtamahan. Ini berarti menerima satu sama lain, berjuang bersama dan melahirkan ide-ide baru bagi kebaikan bersama. Dalam hal ini, komunitas menciptakan etos di mana semua orang dapat terbentuk, rasa sakit dari proses transformasi kebenaran itu ditanggung. Keempat, diam dan bicara. Berbicara adalah karunia yang berharga dan sebagai alat vital dalam sebuah dialog, tetapi di dalam banyak bicara terkandung kesalahan. Jika sebuah ucapan ingin menjadi lebih jujur, haruslah muncul dari dan dikoreksi dalam keheningan atau diam. Kelima, doa. Ini adalah disiplin spiritual dasar yang dapat didefinisikan sebagai praktik ketekaitan. Doa adalah cara menyentuh koneksi dengan dunia dan Roh yang transenden yang darinya segala sesuatu muncul dan kepada siapa semua hal kembali. Doa membawa pada kesadaran akan sebuah 'misteri besar', yang tidak terselami sepenuhnya. Keenam, tatap muka/face to face. Ide Emmanuel Levinas mengenai face to face dengan 'yang lain' adalah bentuk 'wajah'nya kepada seseorang. Dalam pandnagannya, Levinas mengatakan "Manifestasi wajah sudah menjadi diskursus". Tetapi diskursus ini menolak untuk dikungkung. Wajah berbicara, tetapi menolak untuk memiliki. Ini adalah epiphany of the infinite. Begitulah dialog yang melengkapi setiap agama. Ketika seseorang melihat ke mata seseorang yang menderita, tunawisma dan membuat kontak mata, orang itu membiarkan dirinya terbuka sebanyak yang ia bisa terhadap penderitaan itu dan membiarkan orang lain itu membuka dirinya pula (Philips, 2013: 239-244).

Penulis optimis bahwa semua agama dalam kesadaran ini, dapat memberikan kontribusi penting dalam berjalannya "dialog yang sehat dapat berdampak sehat" bagi relasi interreligius di Indonesia. Upaya agama-agama meletakkan keunikan masing-masing, dapat memberikan makna bagi keragaman penghayatan iman. Pendekatan open integrity, bergerak melampaui pluralisme dan relativisme. Warna pendekatan ini: Poin-poin perbedaan, keunikan setiap tradisi, dan apa yang diyakini sebuah agama dieksplorasi dengan khas. Yang diharapkan adalah terjalinnya hubungan yang sehat, demi menciptakan kedamaian bagi keberagaman dan kompleksitas tradisi agama di dunia ini, terkhususnya Indonesia. Bhineka Tunggal Ika, jelas mengajarkan bagi masyarakat Indonesia kesadaran akan perbedaan, keunikan namun terlebih keutuhan kesatuan dalam perspektif yang lebih terbuka. Integritas menjadi akar agama-agama 
demi berjalannya dialog, keterbukaan menjadi asas yang berlaku bagi agama yang berdialog. Open Integrity membuka jalan bagi setiap orang dari latar belakang kepercayaan dan agama serta tradisi yang berbeda di Indonesia untuk masuk dalam sebuah percakapan dan hubungan dengan yang lain, namun juga di sisi lain, Open Integrity menuntut pemeluk agama masuk ke dasar pemahaman tradisi kepercayaannya sendiri secara mendalam, dan membuka jalan yang melampaui tradisi, kepada tradisi lain.

\section{Tentang Penulis}

Yehezkiel Richard H. Siagian, lahir di Palembang, tahun 1993. Program Magister Ilmu Teologi, Fakultas Teologi Universitas Kristen Duta Wacana Yogyakarta, dengan konsentrasi studi Magister Ilmu Teologi (M.Th.), secara khusus mendalami Eklesiologi: studi empiris. Penulis berasal dari Gereja Methodist Indonesia Amplas Medan. E-mail: richard22siagian@gmail.com

\section{Daftar Pustaka}

Buku:

Gratsch, Edward J. 1981. Principles of Catholic Theology, New York: Alba House.

Hick, John H. 1972. The Faith of Other Men, New York: Harper Torchbook.

Lie, Henry E. 1998. Open Particularism: An Evangelical Alternative to Meet the Challenge of Religious Pluralism in the Asian Context (Dissertation), Deerfield, Illinois: Trinity Evangelical Divinity School.

Panikkar, Raimundo. 1978. The Interreligious Dialogue, New York: Paulist Press.

Philips, Gerardette. 2013. Beyond Pluralism, Open Integrity as a Suitable Approach to MuslimChristian Dialogue, Yogyakarta: Interfidei.

Rahner, Karl (ed.). 1969. Sacramentum Mundi, London: Burns and Oates.

Riyanto, E. Armada. 2014. Dialog Interreligius, Historisitas, Tesis, Pergumulan, Wajah, Yogyakarta: Kanisius.

Swidler, Leonard. 1987. Toward a Universal Theology of Religion, Maryknoll: New York Orbis Books.

Tillich, Paul. 1951. Christianity and the Encounter of The World Religious, Vol.1, New York: Columbia University Press.

Tracy, David. 1990. Dialogue with the Other: The Interreligious Dialogue, Luvain Peters Press. 
Jurnal/Artikel:

Banawiratma, J.B., SJ. 1991. "Wujud Baru Hidup Menggereja: Dialogal dan Transformatif", dalam Orientasi Baru, No. 5 Tahun 1991.

Kung, Hans. 1980. "Toward A New Consensus in Catholic (and Ecumenical) Theology", Journal of Ecumenical Studies, Vol. 17 No.1, Winter.

Pattipeilohy, Stella Y.E. 2018. "Ketuhanan yang Berkebudayaan, Memahami Pancasila sebagai Model Interkulturalitas di Indonesia", Gema Teologika, Vol. 3 No. 2, Oktober 2018, Yogyakarta: UKDW. 
